\title{
Thiamine ameliorates inflammation of the ruminal epithelium of Saanen goats suffering from subacute ruminal acidosis
}

\author{
H. Zhang, ${ }^{1,2} \oplus$ A. L. Peng, ${ }^{1,2}$ F. F. Zhao, ${ }^{1,2} \oplus$ L. H. Yu, ${ }^{1,2}$ M. Z. Wang, ${ }^{1,2}$ J. S. Osorio, ${ }^{3} \oplus$ and H. R. Wang ${ }^{1,2 *} \oplus$ \\ ${ }^{1}$ Laboratory of Metabolic Manipulation of Herbivorous Animal Nutrition, College of Animal Science and Technology, Yangzhou University, \\ Yangzhou, 225009, P. R. China \\ ${ }^{2}$ Joint International Research Laboratory of Agriculture and Agri-Product Safety, Ministry of Education of China, Yangzhou University, Yangzhou, \\ 225009, P. R. China \\ ${ }^{3}$ Dairy and Food Science Department, South Dakota State University, Brookings 57007
}

\section{ABSTRACT}

This study aimed to examine the role of thiamine in the local inflammation of ruminal epithelium caused by high-concentrate diets. Eighteen mid-lactating (148 \pm $3 \mathrm{~d}$ in milk; milk yield $=0.71 \pm 0.0300 \mathrm{~kg} / \mathrm{d}$ ) Saanen goats (body weight $=36.5 \pm 1.99 \mathrm{~kg}$; body condition score $=2.73 \pm 0.16$, where $0=$ emaciated and $5=$ obese) in parity 1 or 2 were selected. The goats were randomly divided into 3 groups $(\mathrm{n}=6$ /group): (1) control diet (concentrate:forage 30:70), (2) high-concentrate diet (HC; concentrate:forage 70:30), and (3) highconcentrate diet with $200 \mathrm{mg}$ of thiamine $/ \mathrm{kg}$ of dry matter intake (THC; concentrate:forage 70:30). Goats remained on experimental diets for $8 \mathrm{wk}$. On the last day of $8 \mathrm{wk}$, ruminal and blood samples were collected to determine ruminal parameters, endotoxin lipopolysaccharide, and blood inflammatory cytokines. Goats were slaughtered to collect ruminal tissue to determine gene and protein expression of toll-like receptor 4 (TLR4) signaling pathways. Thiamine supplementation increased ruminal $\mathrm{pH}$ (6.03 vs. 5.42) compared with the HC group. Propionate (21.08 vs. $31.61 \mathrm{mM})$, butyrate (12.08 vs. $19.39 \mathrm{mM})$, lactate $(0.52$ vs. $0.71 \mathrm{mM})$, and free lipopolysaccharide (42.16 vs. $55.87 \times 10^{3}$ endotoxin units $/ \mathrm{mL}$ ) concentrations in ruminal fluid were lower in THC goats compared with HC goats. Similar to plasma interleukin $1 \beta$ (IL-1 $\beta$ ) concentration (209.31 vs. 257.23 $\mathrm{pg} / \mathrm{mL}$ ), blood $\mathrm{CD}^{+}$percentage $(27.57$ vs. $34.07 \%$ ) also decreased in response to thiamine. Compared with HC goats, THC goats had lower ruminal epithelium activity of the enzymes myeloperoxidase and matrix metalloproteinase (MMP) 2 and 9. In contrast to HC, THC had downregulated mRNA expression of nuclear factor-kB $(N F K B), T L R 4, I L 1 B, M M P 2$, and MMP9 in ruminal epithelium. Thiamine supplementation led to

Received May 10, 2019.

Accepted October 20, 2019

*Corresponding author: hrwang@yzu.edu.cn lower relative protein expression of IL-1 $\beta, N F-\kappa B$ unit p65, and phosphorylated NF- $\mathrm{BB}$ unit p65 in ruminal epithelium. Taken together, these results suggest that thiamine supplementation mitigates $\mathrm{HC}$-induced local inflammation and ruminal epithelial disruption.

Key words: dairy goat, subacute ruminal acidosis, inflammation, thiamine

\section{INTRODUCTION}

High-concentrate diets are frequently used in ruminants to improve milk production efficiency. However, high-concentrate diets may cause metabolic dysfunction as well as systemic diseases (Chang et al., 2015). Subacute ruminal acidosis, one the most critical and endemic metabolic dysfunctions in ruminants, is characterized by a ruminal $\mathrm{pH}$ of $<5.8$ for more than $3 \mathrm{~h}$ daily (Plaizier et al., 2008). This reduced ruminal $\mathrm{pH}$ can damage the ruminal epithelium and decrease its barrier function, which results in a translocation of ruminal LPS endotoxin into the bloodstream (Khafipour et al., 2009a). The LPS released into the bloodstream increases the risks of low DMI, laminitis, hepatic abscesses, and inflammatory response, which have a tremendous economic cost to the dairy industry (Gozho et al., 2006; Plaizier et al., 2012). Furthermore, according to Nocek (1997), LPS absorbed from rumen fluid could modify local blood circulation and coagulation, causing microcirculation abnormalities and laminitis. However, the work of Gozho et al. (2007) indicated that even during SARA only a small amount of LPS is absorbed, thus confirming the efficient removal of LPS through the portal circuit even under acidotic conditions.

Thiamine plays a key role in carbohydrate metabolism and is necessary for normal cellular function and growth. Miller et al. (1986) reported that ruminants do not require dietary thiamine because this vitamin is synthesized by ruminal microbes. However, Karapinar et al. (2010) and Pan et al. (2016) found that SARA can produce thiamine deficiency in sheep and cattle. This 
deficiency was associated with increased degradation of thiamine by thiaminase as well as reduced thiamine synthetic activity in microbes during high-grain-induced SARA conditions (Brent, 1976). Interestingly, thiamine supplementation when feeding high-concentrate diets can increase ruminal $\mathrm{pH}$ with a concomitant decrease in ruminal lactate concentration (Pan et al., 2016) and increase ruminal cellulolytic bacteria populations (Pan et al., 2017a).

In addition to carbohydrate metabolism, thiamine plays a critical part in regulating inflammation (Hazell and Butterworth, 2009). Exogenous thiamine administration reduced LPS level and suppressed nuclear factor $(\mathbf{N F})-\kappa \mathrm{B}$ activation, which could jointly lower the proinflammatory cytokine production, thus mitigating local inflammation in ruminal epithelium (Pan et al., 2017b). Studies have also indicated that thiamine administration has a positive effect on inflammation and immune response in both humans (González-Ortiz et al., 2011) and rats (Shoeb and Ramana, 2012). To the authors' knowledge, the anti-inflammatory effects of thiamine have not been reported in dairy goats. Thus, we hypothesized that thiamine supplementation could ameliorate inflammation of ruminal epithelium of Saanen goats suffering SARA. Therefore, the objective of this study was to evaluate the ability of supplemented thiamine to reverse the adverse effects of high-concentrate diets on function and integrity of the ruminal epithelium and further inflammatory response, which

Table 1. Ingredients and nutritional composition of $\operatorname{diets}^{1}$ offered to lactating Saanen goats

\begin{tabular}{lrrr}
\hline Item & CON & HC & THC \\
\hline Ingredient (\% of DM) & & & \\
Chinese wildrye hay & 70.00 & 30.00 & 30.00 \\
Corn grain & 14.00 & 58.90 & 58.90 \\
Soybean meal & 13.00 & 8.45 & 8.45 \\
Calcium hydrophosphate & 1.42 & 0.53 & 0.53 \\
Limestone & 0.58 & 1.12 & 1.12 \\
Salt & 0.50 & 0.50 & 0.50 \\
Premix & 0.50 & 0.50 & 0.50 \\
Nutrient composition & & & \\
ME (MJ/kg of DM) & 8.81 & 11.72 & 11.72 \\
CP (\% of DM) & 10.81 & 10.79 & 10.79 \\
NDF (\% of DM) & 44.28 & 26.71 & 26.71 \\
ADF (\% of DM) & 23.89 & 13.27 & 13.27 \\
Starch (\% of DM) & 23.16 & 48.38 & 48.38 \\
Calcium (\% of DM) & 0.81 & 0.78 & 0.78 \\
Phosphorus (\% of DM) & 0.47 & 0.42 & 0.42 \\
Thiamine (mg/kg of DM) & 1.20 & 1.90 & 201.90 \\
\hline CON control HC & &
\end{tabular}

$\overline{{ }^{1} \mathrm{CON}}=$ control; $\mathrm{HC}=$ high-concentrate diet; $\mathrm{THC}=$ high-concentrate diet supplemented with $200 \mathrm{mg}$ of thiamine $/ \mathrm{kg}$ of DMI.

${ }^{2}$ Premix consisted of the following ingredients per kilogram of diet: $6.00 \times 10^{3} \mathrm{IU}$ of vitamin A, $3.0 \times 10^{3} \mathrm{IU}$ of vitamin $\mathrm{D}, 82.0 \mathrm{mg}$ of vitamin E, $6.15 \mathrm{mg}$ of $\mathrm{Cu}, 70.0 \mathrm{mg}$ of $\mathrm{Fe}, 65.0 \mathrm{mg}$ of $\mathrm{Zn}, 47.0 \mathrm{mg}$ of $\mathrm{Mn}, 0.135 \mathrm{mg}$ of I, $0.115 \mathrm{mg}$ of $\mathrm{Co}$, and $0.115 \mathrm{mg}$ of Mo. in turn can impair overall health and performance in lactating dairy goats.

\section{MATERIALS AND METHODS}

All procedures in this study were performed according to the Animal Protection Law based on the Guide for the Care and Use of Laboratory Animals approved by the Ethics Committee of Yangzhou University (SXXY 2015-0054).

\section{Chemicals}

Dietary thiamine (thiamine hydrochloride $\geq 99 \%$ pure) was obtained from Wanrong Science and Technology Development Co. Ltd. (Wuhan, China). Analytical-grade chloroform and isopropanol were acquired from Shanghai Lingfeng Chemical (Shanghai, China). Ultrapure water was obtained using a Milli-Q system (Millipore, Bedford, MA). Pure $\mathrm{H}_{2}(99.99 \%), \mathrm{N}_{2}$ (99.99\%), and He (99.99\%) were obtained from Jiangsu Tianhong Chemical (Nanjing, China).

\section{Animals and Experimental Design}

Eighteen mid-lactating $(148 \pm 3$ DIM; milk yield $=$ $0.71 \pm 0.0300 \mathrm{~kg} / \mathrm{d}$ ) Saanen goats (body weight $=36.5$ $\pm 1.99 \mathrm{~kg}$; body condition score $=2.73 \pm 0.16$, where $0=$ emaciated and $5=$ obese; Russel et al., 1969) in parity 1 or 2 were selected. The goats were randomly assigned to 1 of 3 diets: (1) control diet $(\mathbf{C O N}$; n = 6; concentrate:forage 30:70), (2) high-concentrate diet (HC; $\mathrm{n}=6$; concentrate:forage 70:30), and (3) highconcentrate diet with $200 \mathrm{mg}$ of thiamine/ $\mathrm{kg}$ of DMI (THC; $\mathrm{n}=6$; concentrate:forage 70:30). The thiamine dose was chosen according to prior dose-response trials in lambs (Neville et al., 2010), dairy goats (Hongwei et al., 2010), and cows (Zhang et al., 2014; Pan et al., $2017 \mathrm{~b}$ ). After being drenched with $0.2 \mathrm{mg}$ of ivermectin/kilogram of BW against endoparasites, goats were maintained under their assigned diets for $8 \mathrm{wk}$. The diet formulation is presented in Table 1. Chinese wildrye was the main forage in the diet. The thiamine concentration in feeds was extracted in accordance with the Chinese National Standard (GB/T 14700-2002; Analytical Methods Committee, 2000) and measured using a commercial ELISA kit (TSZ Biological Trade Co. Ltd., Boston, MA; Pan et al., 2016, 2017b).

Goats were housed in individual pens $(1.3 \times 1.3 \mathrm{~m})$ and offered a TMR fed twice daily at 0700 and 1800 h. Goats had free access to water. The particle size of the pelleted TMR was $6 \mathrm{~mm}$. Feed offered and orts were recorded daily, and samples of diets and orts were 
collected daily and pooled for each goat. The entire experiment lasted $8 \mathrm{wk}$, and all goats were slaughtered at the end of the experiment, $4 \mathrm{~h}$ following the final feeding.

\section{Sample Collection}

Immediately after slaughter, a representative sample of ruminal digesta (at least $200 \mathrm{~mL}$ ) was collected from the ruminal ventral sac at $4 \mathrm{~h}$ after feeding in a local slaughterhouse on the last day of $8 \mathrm{wk}$ of the trial (Liu et al., 2013; Zhang et al., 2018b). After collection, ruminal fluid was filtered through 4 layers of cheesecloth, and the $\mathrm{pH}$ was measured with a $\mathrm{pH}$ meter (Sartorius, Goettingen, Germany). The filtered ruminal fluid samples were centrifuged at $10,000 \times g$ for $15 \mathrm{~min}$ at $4^{\circ} \mathrm{C}$. Five milliliters of clear supernatant samples was transferred into tubes and stored at $-20^{\circ} \mathrm{C}$ for analysis of thiamine. The clear supernatant samples $(2 \mathrm{~mL})$ were used to detect LPS concentration and filtered into a pyrogenfree glass tube and heated at $100^{\circ} \mathrm{C}$ for $30 \mathrm{~min}$. Samples were cooled at room temperature $\left(19^{\circ} \mathrm{C}\right)$ for $10 \mathrm{~min}$ and stored at $-20^{\circ} \mathrm{C}$ for subsequent LPS measurement. Ten milliliters of clear supernatant samples was mixed with $2 \mathrm{~mL}$ of $250 \mathrm{~g} / \mathrm{L}$ metaphosphoric acid and stored at $-20^{\circ} \mathrm{C}$ for VFA and lactate determination. Five milliliters of clear supernatant samples was acidified with 3 drops of sulfuric acid $(18 \mathrm{~mol} / \mathrm{L})$ and stored in the freezer until analyzed for ammonia nitrogen $\left(\mathrm{NH}_{3}-\mathrm{N}\right)$.

Blood samples were collected from the jugular vein using 5-mL vacuum tubes containing sodium heparin (Kindly Enterprise Development Group Co., Ltd., Shanghai, China) and centrifuged at $3,000 \times g$ at $4^{\circ} \mathrm{C}$ for $15 \mathrm{~min}$, and plasma was then preserved at $-20^{\circ} \mathrm{C}$ for subsequent analysis. Finally, all goats were slaughtered to collect the rumen, which was washed with $1 \times$ PBS. Then, about $10 \mathrm{~g}$ of ruminal epithelial samples was obtained from the ventral sac, transferred to liquid $\mathrm{N}$, and preserved at $-80^{\circ} \mathrm{C}$ until further use. For histological analysis, the ventral sac rumen tissues with whole thickness (about $1 \mathrm{~cm}^{2}$ ) were fixed in $4 \%$ paraformaldehyde solution.

\section{Milk Sampling and Analysis}

Goats were milked at 0800 and $1900 \mathrm{~h}$ daily. The daily milk production was recorded using weighing scales (cat. no. PL202-L/01; Mettler Toledo, Shanghai, China). Daily milk samples were taken from both milkings and mixed at a ratio of $6: 4$ for morning $(0800 \mathrm{~h})$ and evening (1900 h) milkings for each goat and were analyzed for milk fat, protein, and lactose contents by mid-infrared spectroscopy (Fossomatic 4000, Foss Electric A/S, Hillerød, Denmark).

\section{Measurements of Physiological Parameters}

The VFA were detected through capillary column gas chromatography (GC-14B, Shimadzu, Kyoto, Japan; Qin, 1982). The lactate concentration in ruminal fluid was measured by enzymatic methods using a commercial kit (A019-2, Nanjing Jiancheng Bioengineering Institute, Nanjing, China) in accordance with the manufacturer's instructions (Jia et al., 2012). Thiamine concentration in ruminal fluid was determined with a commercially available ELISA kit (TSZ Biological Trade Co. Ltd.) following the manufacturer's instructions. Commercial kits were used for determination of pyruvate (cat. no. A081) as well as lactate dehydrogenase (cat. no. A020-2; Nanjing Jiancheng Bioengineering Institute). The pyruvate dehydrogenase (PDH) and $\alpha$-ketoglutarate dehydrogenase ( $\alpha$-KGDHC) concentrations were performed according to procedures described in Yamane et al. (2014) using an ELISA test and measuring the absorbance with a Multiskan MK3 microplate reader (Thermo Labsystems, Philadelphia, PA). The concentration of $\mathrm{NH}_{3}-\mathrm{N}$ in ruminal fluid was determined with a similar colorimetric assay as described by Broderick and Kang (1980). The free LPS in ruminal fluid was detected using a chromogenic endpoint tachypleus amebocyte lysate kit (Chinese Horseshoe Crab Reagent Manufactory, Xiamen, China).

\section{Blood Analyses}

Plasma thiamine and lactate were measured using the same methods described above for ruminal fluid. In the case of LPS concentration in plasma, similar methods described were used with some modifications as described in Khafipour et al. (2009b). Briefly, the frozen plasma samples were thawed at $37^{\circ} \mathrm{C}$ and vortexed, and $100 \mu \mathrm{L}$ of sample was diluted at least 10 times using the tachypleus amebocyte lysate solution. This approach had a lower detection limit of plasma LPS of 0.1 endotoxin units $/ \mathrm{mL}$.

Lymphocyte differential count was performed within $2 \mathrm{~h}$ after collection via flow cytometry using the Advia 2120 Hematology System (Bayer HealthCare, Tarrytown, NY). Briefly, blood samples $(200 \mu \mathrm{L})$ were mixed with $2 \mathrm{~mL}$ of erythrocyte lysing solution, and the erythrocyte-free leukocytes were further mixed with $1 \times$ PBS $(\mathrm{pH} 7.4)$ followed by centrifugation at 1,500 $\times g$ at $4^{\circ} \mathrm{C}$ for $7 \mathrm{~min}$. Then, the purified leukocytes were resuspended to $1 \times 10^{6}$ cells $/ \mathrm{mL}$ followed by staining with primary antibodies mouse anti-sheep CD4 (mAb, MCA2213F, IgG2a) and mouse anti-sheep CD8 (MCA2216PE, IgG2a) and the secondary antibodies fluorescein isothiocyanate (FITC) and phycoerythrin $(\mathbf{P E})$, respectively. All antibodies (AbD Serotec, Ra- 
leigh, NC) were used at the predetermined dilutions. The conjugated PE and FITC isotype antibodies (4ABIO, Beijing, China) were used as the controls, which included mouse IgG2a-PE (FMCP002-100) as well as mouse IgG2a-FITC (FMCF002-100). Cells were incubated with antibodies at $4^{\circ} \mathrm{C}$ for $30 \mathrm{~min}$, followed by resuspending in the staining buffer and washing before analysis through flow cytometry (FACS-Calibur, Becton Dickinson, Franklin Lakes, NJ). For each sample, at least 10,000 data events were extracted and analyzed using Cell Quest (Becton Dickinson; Zhang et al., 2018a).

\section{Plasma Cytokines and Ig Subsets}

Tumor necrosis factor $\alpha$ (TNF- $\alpha$; R\&D Systems, Oxford, UK), IgA (Bethyl Laboratories Inc., Montgomery, TX), IL-10 (BioSource/MED Probe, Camarillo, CA), and IL-1 $\beta$ (R\&D Systems) were determined using commercial kits. The absorbance at $450 \mathrm{~nm}$ was measured using a BioTek Synergy HT microplate reader (BioTek Instruments, Winooski, VT). The limits for detection were $30.0 \mathrm{pg} / \mathrm{mL}, 8.0 \mathrm{pg} / \mathrm{mL}, 12.5 \mathrm{ng} / \mathrm{mL}$, and $7.0 \mathrm{pg} /$ $\mathrm{mL}$ for IL-1 $\beta$, IL-10, IgA, and TNF- $\alpha$, respectively, and neither inter- nor intra-assay coefficient of variation were over 10\% (Zhang et al., 2018a).

\section{Histological Analysis}

Ruminal tissues were fixed by immersion in $4 \%$ paraformaldehyde solution for $72 \mathrm{~h}$, followed by ethanol dehydration and paraffin embedding. Then, the ruminal tissues were cut into sections of $5-\mu \mathrm{m}$ thickness, which were mounted on slides and stained with hematoxylin and eosin (Aguirre et al., 2014). Subsequently, the morphology of tissues was observed under an optical microscope, and images were captured. The layer thickness of the ruminal epithelium was measured as described by Liu et al. (2013). Eight specimens were prepared for each animal, and 5 fields of view were analyzed for each of them.

\section{Detection of Myeloperoxidase Activity}

Myeloperoxidase (MPO) activity was detected with the MPO kit (Nanjing Jiancheng Bioengineering Institute) in accordance with the manufacturer's protocol. Moreover, the absorbance in colorimetry was detected with a spectrophotometer; MPO activity was expressed in units per gram of wet tissue (Dai et al., 2017).

\section{Gelatin Zymography Analysis}

The matrix metalloproteinase (MMP)-2 and MMP9 activities were assessed through gelatin zymography.
Total protein was extracted from $100 \mathrm{mg}$ of ground ruminal epithelium sample for modified gelatin zymography analysis, according to Lee et al. (2014). After extraction, $60 \mu \mathrm{g}$ of total protein was loaded to a $12 \%$ polyacrylamide gel containing $1 \%$ gelatin, followed by electrophoresis at a constant voltage of $100 \mathrm{~V}$ for 90 min. Then, the gel was incubated with a renaturated buffer for $30 \mathrm{~min}$ at ambient temperature, followed by incubation with a developing buffer for $36 \mathrm{~h}$ at $37^{\circ} \mathrm{C}$. After incubation, the gel was stained with $0.5 \%$ Coomassie blue R-250 for $3 \mathrm{~h}$ and washed 3 times with different destaining buffers. Then, the relative zymographic intensity was analyzed with Quantity One software (Bio-Rad Laboratories Inc., Hercules, CA). All experiments were repeated twice, and relative intensity values were calculated.

\section{Total RNA Extraction and Real-Time Quantitative PCR}

Total RNA was extracted from the frozen ruminal samples using TRIzol reagent (Invitrogen Life Technologies, Gaithersburg, MD), and the purity as well as the quality of the extracted RNA were assessed by electrophoresis (A260/A280, Beckman DU-800, Beckman Coulter Inc., Fullerton, CA). Then, $100 \mathrm{ng}$ of RNA was used to synthesize cDNA within the $20-\mu \mathrm{L}$ reaction system. The real-time quantitative PCR was performed using an ABI-7900HT instrument (Applied Biosystems, Foster City, CA). The reaction was carried out in $10 \mu \mathrm{L}$ of reaction mixture containing $0.2 \mu \mathrm{L}$ of ROX Reference Dye II (Takara Bio, Otsu, Japan), $5 \mu \mathrm{L}$ of SYBR Premix Ex TaqII (Tli RNaseH Plus; TaKaRa Biotechnology Co. Ltd., Dalian, China), $1 \mu \mathrm{L}$ of cDNA, $0.4 \mu \mathrm{L}$ of each primer (forward and reverse), and $3 \mu \mathrm{L}$ of diethyl pyrocarbonate-treated water. The real-time quantitative PCR was performed as follows: $30 \mathrm{~s}$ at $95^{\circ} \mathrm{C} ; 40$ cycles of $5 \mathrm{~s}$ at $95^{\circ} \mathrm{C}$ and $31 \mathrm{~s}$ at $60^{\circ} \mathrm{C}$; $15 \mathrm{~s}$ at $95^{\circ} \mathrm{C} ; 1 \mathrm{~min}$ at $60^{\circ} \mathrm{C}$; and $15 \mathrm{~s}$ at $95^{\circ} \mathrm{C}$. The amplification efficiency was derived according to the method described by Chen et al. (2012). The correlation coefficients of all standard curves were $>0.99$, and the range of amplification efficiency was 90 to $110 \%$. The specificity of amplification was also examined by melting curve. The $\beta$-actin $(A C T B)$ gene was used as the internal control gene; this was used to normalized the gene expression data from target genes, and the relative gene expression was analyzed according to the $2^{-\Delta \Delta \mathrm{Ct}}$ method (Livak and Schmittgen, 2001). The primer sequences are listed in Table 2 . The mRNA level of each target gene was expressed relative to the CON group. Although $A C T B$ has been found to have a high degree of stability in similar samples and has been previously used as an internal control gene (Zhang et al., 
Table 2. Real-time PCR primer list of target genes

\begin{tabular}{|c|c|c|}
\hline $\begin{array}{l}\text { Target } \\
\text { gene }^{1}\end{array}$ & Primer sequence $\left(5^{\prime}-3^{\prime}\right)^{2}$ & $\begin{array}{l}\text { Reference/GenBank } \\
\text { accession no. }\end{array}$ \\
\hline$\overline{N F K B}$ & $\begin{array}{l}\text { F: CTCACCAATGGCCTCCTCTC } \\
\text { R: ACACCCTCCCAGAATCCGTA }\end{array}$ & XM_005699996.1 \\
\hline$I L 6$ & $\begin{array}{l}\text { F: CCAATCTGGGTTCAATCAGG } \\
\text { R: ACCCACTCGTTTGAGGACTG }\end{array}$ & D86569.1 \\
\hline$I L 8$ & $\begin{array}{l}\text { F: ATGGAACAATGTACATGTGACAC } \\
\text { R: CTGAGAGTTATTGAGAGTGGGC }\end{array}$ & XM_005681749.1 \\
\hline$T N F A$ & $\begin{array}{l}\text { F: CAAGTAACAAGCCGGTAGCC } \\
\text { R: AGATGAGGTAAAGCCCGTCA }\end{array}$ & X14828.1 \\
\hline$T L R 4$ & $\begin{array}{l}\text { F: TTCGCATCTGGATAAATCCAGC } \\
\text { R: CTGAGAACCGAGAGCTGGGAC }\end{array}$ & NM_001285574.1 \\
\hline$C D 68$ & $\begin{array}{l}\text { F: CAGATGCGAGTTCTGTACCCA } \\
\text { R: CCAGGAAGACTGTTTGAATCCGA }\end{array}$ & XM_005693516.1 \\
\hline IL10 & $\begin{array}{l}\text { F: TTAAGGGTTACCTGGGTTGC } \\
\text { R: CCCTCTCTTGGAGCATATTGA }\end{array}$ & DQ837159.1 \\
\hline$I L 1 B$ & $\begin{array}{l}\text { F: CATGTGTGCTGAAGGCTCTC } \\
\text { R: AGTGTCGGCGTATCACCTTT }\end{array}$ & D63351.1 \\
\hline$M M P 2$ & $\begin{array}{l}\text { F: AGGACGGCAAGTATGGCTTC } \\
\text { R: CCCATTGCATGGCCAAACTC }\end{array}$ & XM_005691985.1 \\
\hline$M M P 9$ & $\begin{array}{l}\text { F: ATTCCAGACCTTTGAGGGCG } \\
\text { R: CAGGAGCCCGTTCTTTCCAT }\end{array}$ & XM_005688723.1 \\
\hline$A C T B$ & $\begin{array}{l}\text { F: CTTGATGTCACGGACGATTT } \\
\text { R: CACGGCATTGTCACCAAC }\end{array}$ & XM_018039831.1 \\
\hline
\end{tabular}

2018a), we acknowledge that using more than 1 internal control gene is the most appropriate approach to normalize gene expression data (Kadegowda et al., 2009; Saremi et al., 2012). Therefore, we consider that using $A C T B$ as the only internal control gene is a limitation of this study.

\section{Western Blotting Analysis}

The ground ruminal epithelial sample $(\sim 100 \mathrm{mg})$ was homogenized in $1 \mathrm{~mL}$ of iced radio immunoprecipitation assay protein separation buffer (Beyotime, Shanghai, China) for $15 \mathrm{~s}$, followed by $20 \mathrm{~min}$ of incubation on ice and $30 \mathrm{~min}$ of centrifugation at $12,000 \times \mathrm{g}$ and $4^{\circ} \mathrm{C}$. The supernatant was collected and transferred into another tube. Then, the protein concentration was determined using a BCA Protein Detection kit (Thermo Fisher Scientific Inc., Waltham, MA). Briefly, $60 \mathrm{mg}$ of protein was isolated using 5 and 10\% SDS-PAGE and then transferred to a nitrocellulose membrane (Pall Gelman Laboratory, Ann Arbor, MI). These membranes were blocked with $5 \%$ skim milk $5 \%$ BSA for phosphorylated p65) at $25^{\circ} \mathrm{C}$ for $2 \mathrm{~h}$, followed by an incubation with primary antibodies, including anti-p65 (1:300, sc-109; Santa Cruz Biotechnology Inc., Dallas, TX), anti-p p65 (Ser 536; 1:300, sc-33020; Santa Cruz Biotechnology Inc.), anti-IL-1 $\beta$ (1:300, sc-7884; Santa Cruz Biotechnology Inc.), anti-TNF- $\alpha$ (1:300, sc-8301; Santa Cruz Biotechnology Inc.), anti-IL-6 (1:300, sc-
1265; Santa Cruz Biotechnology Inc.), and anti- $\beta$-actin (1:10,000, BS6007M; Bioworld Technology Inc., St. Louis Park, MN) at $4^{\circ} \mathrm{C}$ overnight. Later, the membranes were washed 6 times with Tris-buffered saline supplemented with Tween 20 (TBST) for $10 \mathrm{~min}$ and incubated with horseradish peroxidase-conjugated secondary antibodies, including goat anti-rabbit (1:5,000, sc-2004; Santa Cruz Biotechnology Inc.) and goat antimouse (1:10,000, SN-133; Sunshine Biotechnology Nanjing Co. Ltd., China), at ambient temperature for $2 \mathrm{~h}$. After incubation, the membranes were washed 6 times with TBST for $10 \mathrm{~min}$, and an ECL Plus kit (Vazyme, Nanjing, China) was used to visualize the results. In addition, an LAS4000 imaging system (GE Healthcare Bio-Sciences AB, Uppsala, Sweden) was used to record signals, and analysis of the signals was done through Quantity One software (Bio-Rad Laboratories Inc.).

\section{Statistical Analysis}

Data were analyzed using SPSS 16.0 software (SPSS Inc., Chicago, IL). The fixed effect of parity was included in the original statistical model and was not significant $(P>0.05)$; thus, it was eliminated from the final model, in which only treatment was the fixed effect. Intergroup difference was determined through 1-way ANOVA as well as Tukey's post hoc test for multiple comparisons. A difference of $P \leq 0.05$ was deemed significant. 
Table 3. Effects of thiamine supplementation on feed intake, milk yield, and milk composition of Saanen goats with SARA

\begin{tabular}{lccccc}
\hline & \multicolumn{5}{c}{ Diet $^{1}$} \\
\cline { 2 - 4 } Item & CON & HC & THC & SEM & P-value \\
\cline { 2 - 5 } DMI (kg/d) & $1.28^{\mathrm{a}}$ & $1.03^{\mathrm{b}}$ & $1.26^{\mathrm{a}}$ & 0.09 & 0.012 \\
Milk yield (kg/d) & $1.25^{\mathrm{a}}$ & $0.93^{\mathrm{b}}$ & $1.28^{\mathrm{a}}$ & 0.07 & 0.024 \\
Milk component (\%) & & & & & \\
$\quad$ Fat & $4.36^{\mathrm{a}}$ & $3.52^{\mathrm{c}}$ & $3.99^{\mathrm{b}}$ & 0.11 & 0.008 \\
Protein & $4.17^{\mathrm{a}}$ & $3.62^{\mathrm{b}}$ & $4.20^{\mathrm{a}}$ & 0.13 & 0.009 \\
$\quad$ Lactose & 4.57 & 4.53 & 4.58 & 0.09 & 0.209 \\
Yield (g/d) & & & & & \\
Fat & $54.5^{\mathrm{a}}$ & $32.74^{\mathrm{b}}$ & $51.01^{\mathrm{a}}$ & 2.14 & 0.025 \\
Protein & $52.13^{\mathrm{a}}$ & $33.67^{\mathrm{b}}$ & $53.76^{\mathrm{a}}$ & 1.59 & 0.009 \\
Lactose & $57.13^{\mathrm{a}}$ & $42.13^{\mathrm{b}}$ & $58.62^{\mathrm{a}}$ & 2.31 & 0.018 \\
\hline
\end{tabular}

${ }^{a-c}$ Within a row, means without a common letter differ $(P<0.05)$.

${ }^{1} \mathrm{CON}=$ control; $\mathrm{HC}=$ high-concentrate diet; $\mathrm{THC}=$ high-concentrate diet supplemented with $200 \mathrm{mg}$ of thiamine/kg of DMI. $\mathrm{n}=6$ goats/group.

\section{RESULTS}

\section{DMI, Milk Production, and Composition}

The HC group had lower $(P<0.05)$ DMI, milk yield, fat percentage, protein percentage, milk fat yield, milk protein yield, and milk lactose yield compared with the $\mathrm{CON}$ and THC groups. These parameters were similar between CON and THC (Table 3).

\section{Ruminal Epithelium Histomorphometry}

Representative histological sections of ruminal epithelium from goats fed CON, HC, and THC diets are shown in Figure 1. In the HC goats (Figure 1B), sloughing of the stratum corneum was evident, and adhesion between cells of the stratum corneum and stratum granulosum appeared to be compromised, as shown by large gaps between cells. However, the ruminal epithelium injury was alleviated in the THC goats (Figure 1C). The thickness of the total epithelium, stratum corneum, stratum granulosum, and stratum spinosum/ basal was lower $(P<0.05)$ in $\mathrm{CON}$ goats than in $\mathrm{HC}$ and THC goats (Table 4). In turn, these variables were lower $(P<0.05)$ in the $\mathrm{HC}$ goats than in the $\mathrm{THC}$ goats.

\section{Ruminal Fermentation and Blood Parameters}

Ruminal $\mathrm{pH}$ and acetate concentration in the $\mathrm{HC}$ group were lower than in the $\mathrm{CON}$ and THC groups $(P<0.05$; Table 5$)$, whereas ruminal $\mathrm{pH}$ and acetate were similar $(P>0.05)$ between the $\mathrm{CON}$ and $\mathrm{THC}$
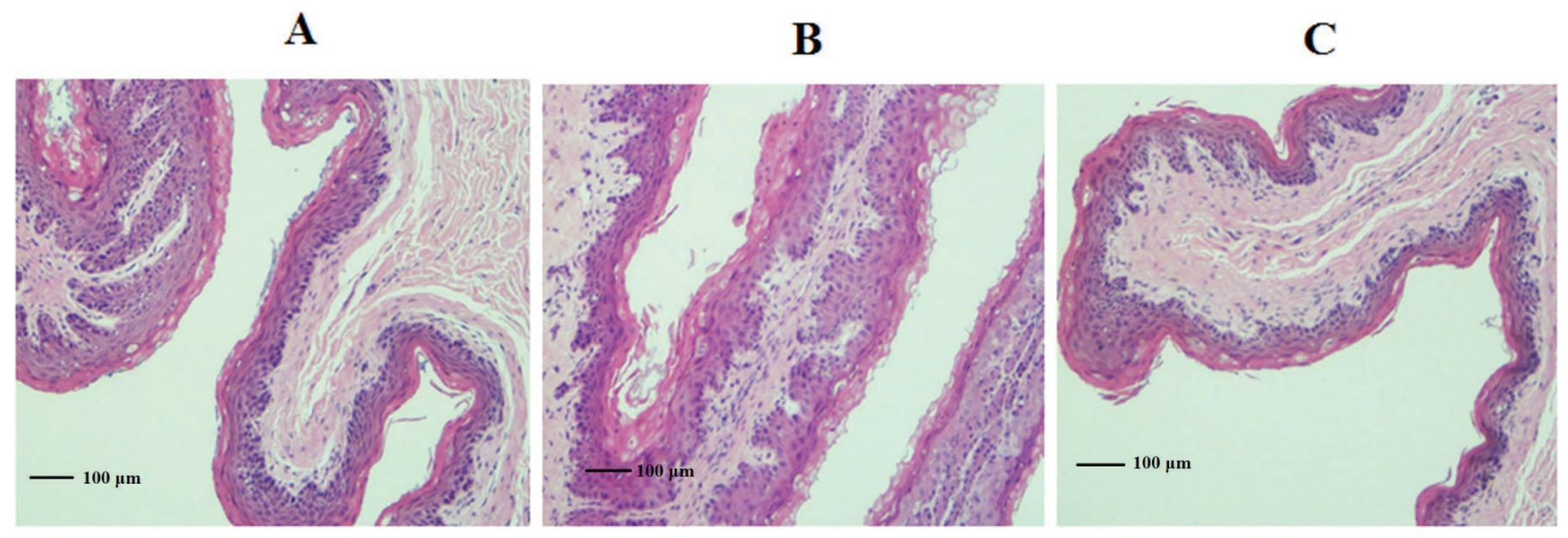

Figure 1. Histologic alteration of the ruminal epithelium in goats from the CON, HC, and THC groups. Light microscopy cross-section of ruminal epithelium from a representative (A) CON goat, (B) HC goat, and (C) THC goat. All sections were stained with hematoxylin and eosin and examined at $100 \times$ magnification. Scale bar $=100 \mu \mathrm{m}$. CON $=$ control; $\mathrm{HC}=$ high-concentrate diet; THC $=$ high-concentrate diet supplemented with $200 \mathrm{mg}$ of thiamine/kg of DMI 
Table 4. Effects of thiamine supplementation on histomorphometric measurement of ruminal epithelium of Saanen goats with SARA

\begin{tabular}{|c|c|c|c|c|c|}
\hline \multirow[b]{2}{*}{ Item } & \multicolumn{3}{|c|}{ Diet $^{1}$} & \multirow[b]{2}{*}{ SEM } & \multirow[b]{2}{*}{$P$-value } \\
\hline & $\mathrm{CON}$ & $\mathrm{HC}$ & $\mathrm{THC}$ & & \\
\hline Thickness of total epithelium $(\mu \mathrm{m})$ & $139.45^{\mathrm{a}}$ & $103.21^{\mathrm{c}}$ & $120.11^{\mathrm{b}}$ & 5.88 & 0.009 \\
\hline Thickness of stratum corneum $(\mu \mathrm{m})$ & $17.19^{\mathrm{a}}$ & $9.21^{\mathrm{c}}$ & $12.46^{\mathrm{b}}$ & 1.04 & 0.011 \\
\hline Thickness of stratum granulosum $(\mu \mathrm{m})$ & $23.12^{\mathrm{a}}$ & $13.32^{\mathrm{c}}$ & $17.52^{\mathrm{b}}$ & 1.75 & 0.006 \\
\hline Thickness of stratum spinosum/basale $(\mu \mathrm{m})$ & $86.54^{\mathrm{a}}$ & $62.13^{\mathrm{c}}$ & $73.08^{\mathrm{b}}$ & 3.46 & 0.007 \\
\hline
\end{tabular}

${ }^{a-c}$ Within a row, means without a common letter differ $(P<0.05)$.

${ }^{1} \mathrm{CON}=$ control; $\mathrm{HC}=$ high-concentrate diet; $\mathrm{THC}=$ high-concentrate diet supplemented with $200 \mathrm{mg}$ of thiamine/kg of DMI. $\mathrm{n}=6$ goats/group.

groups. The CON goats had lower $(P<0.05)$ propionate, butyrate, valerate, isovalerate, total VFA, lactic acid, pyruvate, and free LPS compared with the $\mathrm{HC}$ and THC goats, but these parameters were lower $(P$ $<0.05)$ in THC goats compared with HC goats. The CON goats had greater $(P<0.05)$ acetate:propionate ratio, $\mathrm{NH}_{3}-\mathrm{N}$, thiamine, acetate, and $\mathrm{PDH}$ concentrations in ruminal fluid compared with the $\mathrm{HC}$ and $\mathrm{THC}$ goats, whereas these ruminal parameters were greater $(P<0.05)$ in THC goats than in $\mathrm{HC}$ goats.

Thiamine, $\mathrm{PDH}$, and $\alpha-\mathrm{KGDHC}$ in plasma were greater $(P<0.05)$ in $\mathrm{CON}$ goats than in $\mathrm{HC}$ and $\mathrm{THC}$ goats, whereas these blood parameters were greater $(P$ $<0.05)$ in THC goats than in $\mathrm{HC}$ goats. The CON goats had lower $(P<0.05)$ plasma free LPS, lactate, pyruvate, and lactate dehydrogenase compared with the HC and THC goats, whereas THC goats had lower $(P<0.05)$ concentration of these parameters compared with $\mathrm{HC}$ goats.

\section{Plasma Cytokine, Ig, and Leukocyte Differential}

The $\operatorname{IgA}$ and $\mathrm{CD} 4^{+}: \mathrm{CD}^{+}$ratio as well as neutrophils percentage, lymphocytes percentage, and monocytes

Table 5. Effects of thiamine supplementation on metabolites in the rumen and blood parameters of Saanen goats with SARA

\begin{tabular}{|c|c|c|c|c|c|}
\hline \multirow[b]{2}{*}{ Item $^{1}$} & \multicolumn{3}{|c|}{ Diet $^{2}$} & \multirow[b]{2}{*}{ SEM } & \multirow[b]{2}{*}{$P$-value } \\
\hline & $\mathrm{CON}$ & $\mathrm{HC}$ & $\mathrm{THC}$ & & \\
\hline \multicolumn{6}{|l|}{ Ruminal variables } \\
\hline $\mathrm{pH}$ & $6.11^{\mathrm{a}}$ & $5.42^{\mathrm{b}}$ & $6.03^{\mathrm{a}}$ & 0.11 & 0.003 \\
\hline Thiamine $(\mu \mathrm{g} / \mathrm{L})$ & $7.15^{\mathrm{a}}$ & $2.08^{\mathrm{c}}$ & $4.02^{\mathrm{b}}$ & 0.18 & 0.006 \\
\hline Acetate $(\mathrm{m} M)$ & $38.98^{\mathrm{a}}$ & $27.32^{\mathrm{b}}$ & $37.21^{\mathrm{a}}$ & 2.08 & 0.007 \\
\hline Propionate $(\mathrm{m} M)$ & $15.76^{\mathrm{c}}$ & $31.61^{\mathrm{a}}$ & $21.08^{\mathrm{b}}$ & 1.99 & 0.005 \\
\hline Butyrate $(\mathrm{m} M)$ & $8.53^{\mathrm{c}}$ & $19.39^{\mathrm{a}}$ & $12.08^{\mathrm{b}}$ & 0.87 & 0.008 \\
\hline Isobutyrate $(\mathrm{m} M)$ & 1.12 & 1.36 & 1.28 & 0.12 & 0.078 \\
\hline Valerate $(\mathrm{m} M)$ & $0.42^{\mathrm{c}}$ & $0.88^{\mathrm{a}}$ & $0.64^{\mathrm{b}}$ & 0.04 & 0.003 \\
\hline Isovalerate $(\mathrm{m} M)$ & $0.41^{\mathrm{c}}$ & $0.92^{\mathrm{a}}$ & $0.69^{\mathrm{b}}$ & 0.07 & 0.006 \\
\hline Total VFA $(\mathrm{m} M)$ & $65.22^{\mathrm{c}}$ & $81.48^{\mathrm{a}}$ & $72.98^{\mathrm{b}}$ & 2.09 & 0.009 \\
\hline Acetate:propionate ratio & $2.47^{\mathrm{a}}$ & $0.86^{\mathrm{c}}$ & $1.77^{\mathrm{b}}$ & 0.10 & 0.007 \\
\hline Lactate $(\mathrm{m} M)$ & $0.34^{\mathrm{c}}$ & $0.71^{\mathrm{a}}$ & $0.52^{\mathrm{b}}$ & 0.04 & 0.003 \\
\hline Pyruvate $(\mathrm{m} M)$ & $0.21^{\mathrm{c}}$ & $0.33^{\mathrm{a}}$ & $0.26^{\mathrm{b}}$ & 0.02 & 0.012 \\
\hline $\mathrm{PDH}(\mathrm{IU} / \mathrm{L})$ & $3.12^{\mathrm{a}}$ & $1.03^{\mathrm{c}}$ & $2.38^{\mathrm{b}}$ & 0.11 & 0.009 \\
\hline Free LPS $\left(\times 10^{3} \mathrm{EU} / \mathrm{mL}\right)$ & $25.09^{\mathrm{c}}$ & $55.87^{\mathrm{a}}$ & $42.16^{\mathrm{b}}$ & 3.08 & 0.011 \\
\hline $\mathrm{NH}_{3}-\mathrm{N}(\mathrm{m} M)$ & $24.17^{\mathrm{a}}$ & $11.28^{\mathrm{c}}$ & $17.89^{\mathrm{b}}$ & 1.21 & 0.006 \\
\hline \multicolumn{6}{|l|}{ Blood variables } \\
\hline Free LPS in plasma $(\mathrm{EU} / \mathrm{mL})$ & $0.11^{\mathrm{c}}$ & $0.73^{\mathrm{a}}$ & $0.34^{\mathrm{b}}$ & 0.03 & 0.008 \\
\hline Thiamine $(\mu \mathrm{g} / \mathrm{L})$ & $16.09^{\mathrm{a}}$ & $9.21^{\mathrm{c}}$ & $12.09^{\mathrm{b}}$ & 0.61 & 0.007 \\
\hline Lactate $(\mathrm{m} M)$ & $1.01^{\mathrm{c}}$ & $1.56^{\mathrm{a}}$ & $1.29^{\mathrm{b}}$ & 0.07 & 0.012 \\
\hline Pyruvate $(\mathrm{m} M)$ & $0.18^{\mathrm{c}}$ & $0.32^{\mathrm{a}}$ & $0.24^{\mathrm{b}}$ & 0.02 & 0.021 \\
\hline $\mathrm{PDH}(\mathrm{IU} / \mathrm{L})$ & $1.47^{\mathrm{a}}$ & $0.82^{\mathrm{c}}$ & $1.12^{\mathrm{b}}$ & 0.06 & 0.005 \\
\hline Lactate dehydrogenase (IU/L) & $4,489^{\mathrm{c}}$ & $6,103^{\mathrm{a}}$ & $5,282^{\mathrm{b}}$ & 387.35 & 0.009 \\
\hline$\alpha-K G D H C(\mathrm{mg} / \mathrm{L})$ & $15.82^{\mathrm{a}}$ & $9.23^{\mathrm{c}}$ & $11.99^{\mathrm{b}}$ & 0.68 & 0.004 \\
\hline
\end{tabular}

${ }^{\mathrm{a}-\mathrm{c}}$ Within a row, means without a common letter differ $(P<0.05)$.

${ }^{1} \mathrm{PDH}=$ pyruvate dehydrogenase; $\mathrm{EU}=$ endotoxin unit; $\alpha$-KGDHC $=\alpha$-ketoneglutarate dehydrogenase.

${ }^{2} \mathrm{CON}=$ control; $\mathrm{HC}=$ high-concentrate diet; $\mathrm{THC}=$ high-concentrate diet supplemented with $200 \mathrm{mg}$ of thiamine/kg of DMI. $\mathrm{n}=6$ goats/group. 
Table 6. Effects of thiamine supplementation on plasma IgA and cytokine concentrations, blood leucocytes, neutrophils, lymphocytes, monocytes, and T lymphocyte subsets of Saanen goats with SARA

\begin{tabular}{|c|c|c|c|c|c|}
\hline \multirow[b]{2}{*}{ Item } & \multicolumn{3}{|c|}{$\operatorname{Diet}^{1}$} & \multirow[b]{2}{*}{ SEM } & \multirow[b]{2}{*}{$P$-value } \\
\hline & $\mathrm{CON}$ & $\mathrm{HC}$ & $\mathrm{THC}$ & & \\
\hline IL-1 $(\mathrm{pg} / \mathrm{mL})$ & $172.92^{\mathrm{c}}$ & $257.23^{\mathrm{a}}$ & $209.31^{b}$ & 9.35 & 0.009 \\
\hline TNF- $\alpha^{2}(p g / m L)$ & 112.36 & 114.27 & 110.21 & 6.09 & 0.109 \\
\hline IL-10 (pg/mL) & 60.23 & 64.23 & 62.09 & 3.98 & 0.201 \\
\hline $\operatorname{IgA}(\mathrm{ng} / \mathrm{mL})$ & $50.08^{\mathrm{a}}$ & $39.21^{\mathrm{b}}$ & $48.03^{\mathrm{a}}$ & 2.81 & 0.007 \\
\hline Leukocytes $\left(10^{9} / \mathrm{L}\right)$ & 15.23 & 13.09 & 14.66 & 1.02 & 0.113 \\
\hline Neutrophils $\left(10^{9} / \mathrm{L}\right)$ & 5.13 & 5.05 & 5.11 & 0.88 & 0.182 \\
\hline Lymphocytes $\left(10^{9} / \mathrm{L}\right)$ & 13.67 & 13.29 & 13.33 & 1.08 & 0.216 \\
\hline Monocytes $\left(10^{9} / \mathrm{L}\right)$ & $0.58^{\mathrm{a}}$ & $0.24^{\mathrm{c}}$ & $0.39^{\mathrm{b}}$ & 0.03 & 0.006 \\
\hline Neutrophils (\%) & $20.38^{\mathrm{a}}$ & $11.96^{\mathrm{c}}$ & $16.01^{\mathrm{b}}$ & 1.63 & 0.009 \\
\hline Lymphocytes (\%) & $73.97^{\mathrm{a}}$ & $42.09^{\mathrm{c}}$ & $60.01^{\mathrm{b}}$ & 3.32 & 0.014 \\
\hline Monocytes (\%) & $3.46^{\mathrm{a}}$ & $1.54^{\mathrm{c}}$ & $2.36^{\mathrm{b}}$ & 0.12 & 0.008 \\
\hline $\mathrm{CD}^{+}(\%)$ & 62.95 & 59.37 & 61.09 & 3.76 & 0.107 \\
\hline $\mathrm{CD}^{+}(\%)$ & 36.73 & 34.91 & 35.07 & 2.61 & 0.182 \\
\hline $\mathrm{CD}^{+}(\%)$ & $20.35^{\mathrm{c}}$ & $34.07^{\mathrm{a}}$ & $27.57^{\mathrm{b}}$ & 2.07 & 0.011 \\
\hline $\mathrm{CD} 4^{+}: \mathrm{CD}^{+}$ & $1.66^{\mathrm{a}}$ & $0.85^{\mathrm{c}}$ & $1.29^{\mathrm{b}}$ & 0.10 & 0.007 \\
\hline
\end{tabular}

${ }^{\mathrm{a}-\mathrm{c}}$ Within a row, means without a common letter differ $(P<0.05)$.

${ }^{1} \mathrm{CON}=$ control; $\mathrm{HC}=$ high-concentrate diet; $\mathrm{THC}=$ high-concentrate diet supplemented with $200 \mathrm{mg}$ of thiamine/kg of DMI. $\mathrm{n}=6$ goats/group.

${ }^{2}$ Tumor necrosis factor $\alpha$.

percentage in plasma were greater $(P<0.05)$ in $\mathrm{CON}$ goats than in $\mathrm{HC}$ and $\mathrm{THC}$ goats, whereas these blood parameters were greater $(P<0.05)$ in THC goats than in $\mathrm{HC}$ goats (Table 6 ). Plasma IL- $1 \beta$ and $\mathrm{CD} 8^{+}$percentage were lower $(P<0.05)$ in CON goats than in $\mathrm{HC}$ and THC goats, but these were lower $(P<0.05)$ in THC goats than in $\mathrm{HC}$ goats.

\section{MPO, MMP-2, and MMP-9 Activities in Ruminal Epithelium}

The MPO, MMP-2, and MMP-9 activities in ruminal epithelium were lower $(P<0.05)$ in CON goats than in $\mathrm{HC}$ and THC goats (Table 7 ), whereas the activity of these enzymes was lower $(P<0.05)$ in THC goats than in $\mathrm{HC}$ goats.

\section{mRNA Abundance of Genes in Ruminal Epithelium}

The mRNA expression of NFKB, IL6, IL8, TNF, TLR 4, CD68, IL10, IL1B, MMP2, and MMP9 in ruminal epithelium was downregulated $(P<0.05)$ in $\mathrm{CON}$ goats compared with $\mathrm{HC}$ and THC goats (Table 8 ). In turn, the expression of these genes was downregulated in THC goats compared with HC goats.

\section{Relative Protein Expression in Rumen Epithelium}

The relative protein expression of IL- 6 , TNF- $\alpha$, IL$1 \beta$, p65, and p-p65 in ruminal epithelium was downregulated $(P<0.05)$ in CON goats compared with $\mathrm{HC}$ and THC goats (Figure 2). However, these proinflam- matory cytokines were downregulated $(P<0.05)$ in THC goats compared with HC goats.

\section{DISCUSSION}

\section{Effect of Thiamine Supplementation on $\mathrm{pH}$ and LPS Concentration in the Rumen}

In the short term the $\mathrm{HC}$ diet increased daily milk yield, but in the long term offering this diet may be detrimental to the animal's health by reducing ruminal pH (Castrillo et al., 2013), initiating an inflammatory response (Emmanuel et al., 2008), and, in extreme cases, causing death. Additionally, a reduced ruminal $\mathrm{pH}$ can lead to ruminal epithelial deterioration (Steele et al., 2009), which can, in turn, facilitate the passage of pathogens from the rumen to the bloodstream and predispose the animal to systemic inflammation.

In the current study, we observed that the ruminal $\mathrm{pH}$ in $\mathrm{HC}$ goats was reduced compared with that in CON goats. However, thiamine supplementation in the THC group was able to reverse the high-grain effect on ruminal $\mathrm{pH}$ by promoting a more basic $\mathrm{pH}$, which was comparable with that of CON goats. In contrast to ruminal $\mathrm{pH}$, feeding an $\mathrm{HC}$ diet resulted in accumulation of VFA in the rumen (Table 5). The latter could be associated with a greater rate of carbohydrate fermentation in the rumen, which is typically accompanied by a reduction in ruminal $\mathrm{pH}$. This condition, if prolonged enough, could lead to the onset of SARA and consequently disturb the equilibrium essential for maintaining a diverse multispecies microbiota while 
Table 7. Effects of thiamine supplementation on the activities of myeloperoxidase (MPO) and matrix metalloproteinase (MMP) 2 and 9 in ruminal epithelium of Saanen goats with SARA

\begin{tabular}{|c|c|c|c|c|c|}
\hline \multirow[b]{2}{*}{ Item } & \multicolumn{3}{|c|}{ Diet $^{1}$} & \multirow[b]{2}{*}{ SEM } & \multirow[b]{2}{*}{$P$-value } \\
\hline & $\mathrm{CON}$ & $\mathrm{HC}$ & $\mathrm{THC}$ & & \\
\hline $\begin{array}{l}\text { MPO (unit/g of wet tissue) } \\
\text { MMP-2 (relative intensity) } \\
\text { MMP-9 (relative intensity) }\end{array}$ & $\begin{array}{l}3.08^{\mathrm{c}} \\
0.88^{\mathrm{c}} \\
0.84^{\mathrm{c}}\end{array}$ & $\begin{array}{l}6.68^{\mathrm{a}} \\
2.76^{\mathrm{a}} \\
2.56^{\mathrm{a}}\end{array}$ & $\begin{array}{l}4.83^{\mathrm{b}} \\
1.73^{\mathrm{b}} \\
1.61^{\mathrm{b}}\end{array}$ & $\begin{array}{l}0.86 \\
0.10 \\
0.13\end{array}$ & $\begin{array}{l}0.006 \\
0.012 \\
0.009\end{array}$ \\
\hline
\end{tabular}

promoting specific bacteria species such as Selenomonas ruminantium, which can exacerbate SARA conditions (Fernando et al., 2010). Similar to our results, others have observed that changes in ruminal $\mathrm{pH}$ and bacteria species have been associated with excessive LPS release, which leads to an increased LPS in the rumen (Li et al., 2012).

Supplementation of thiamine increased $\mathrm{pH}$ while reducing the LPS concentration in the rumen of THC goats, and this effect could be partially ascribed to the improvement in microbial composition. In agreement with our results, others have observed that greater ruminal thiamine concentration may benefit the protozoa population (Holtershinken et al., 2003) while promoting certain microbial species such as Megasphaera elsdenii over others that are associated with SARA, including Streptococcus bovis (Wang et al., 2015). Hence, thiamine supplementation can modulate ruminal microbial populations and promote a less acidic ruminal environment, eventually leading to a lower LPS level from bacterial lysis. Mao et al. (2016) showed that high-grain-induced SARA could increase the Firmicutes phylum popula-

Table 8. Effects of thiamine supplementation on the mRNA abundance of genes in the ruminal epithelium of Saanen goats with SARA

\begin{tabular}{lccccc}
\hline & \multicolumn{5}{c}{ Diet $^{2}$} \\
Item
\end{tabular}

${ }^{\mathrm{a}-\mathrm{c}}$ Within a row, means without a common letter differ $(P<0.05)$.

${ }^{1} N F K B=$ nuclear factor kappa B (p65); TNFA = tumor necrosis factor $\alpha ; T L R 4=$ toll-like receptor $4 ; M M P=$ matrix metalloproteinase. ${ }^{2} \mathrm{CON}=$ control; $\mathrm{HC}=$ high-concentrate diet; $\mathrm{THC}=$ high-concentrate diet supplemented with $200 \mathrm{mg}$ of thiamine/kg of DMI. $\mathrm{n}=6$ goats/group. tion, which was positively correlated with the ruminal LPS (Lau et al., 2016). Pan et al. (2017b) suggested that the increased Firmicutes population while feeding high-concentrate diets was suppressed by thiamine supplementation, which might further decrease the free LPS concentration in ruminal fluid, which was consistent with our findings.

\section{Effects of Thiamine Supplementation on Ruminal Metabolites and Blood Parameters}

Thiamine is a coenzyme required for the activity of $\mathrm{PDH}$ and $\alpha-\mathrm{KGDHC}$, which are directly related to carbohydrate metabolism (Bubber et al., 2004). Thiamine deficiency can cause the accumulation of pyruvate, and then pyruvate is converted into lactate by lactate dehydrogenase (Kumar et al., 2015). Therefore, it is conceivable that thiamine requirements may increase when feeding a high-grain diet to ruminants to compensate for the carbohydrate overload (Edwin and Jackman, 1970). Goats in the HC group in our study were under SARA conditions and had greater plasma lactate and lactate dehydrogenase activity concomitantly with lower plasma thiamine and $\alpha-\mathrm{KGDHC}$ activity, which confirms that thiamine deficiency occurs during SARA. Similar to our results in goats, thiamine deficiency also developed when subacute or acute ruminal acidosis occurred in sheep (Karapinar et al., 2008, 2010).

Overall, our findings indicate that thiamine supplementation can improve plasma thiamine concentrations as well as PDH and $\alpha-\mathrm{KGDHC}$ activity. These effects allow an increased channeling of pyruvate into the tricarboxylic acid (TCA) cycle and consequently decreased lactate and the lactate dehydrogenase activity in goats fed a THC diet. These results are in agreement with previous findings reported by Pan et al. (2016), who observed that thiamine supplementation increased serum thiamine; this was accompanied by a reduction of blood pyruvate and lactate. An increase in blood thiamine will likely enhance plasma $\mathrm{PDH}$ and $\alpha$-KGDHC activity. According to our results, the increased enzyme activity of PDH and $\alpha-\mathrm{KGDHC}$ 

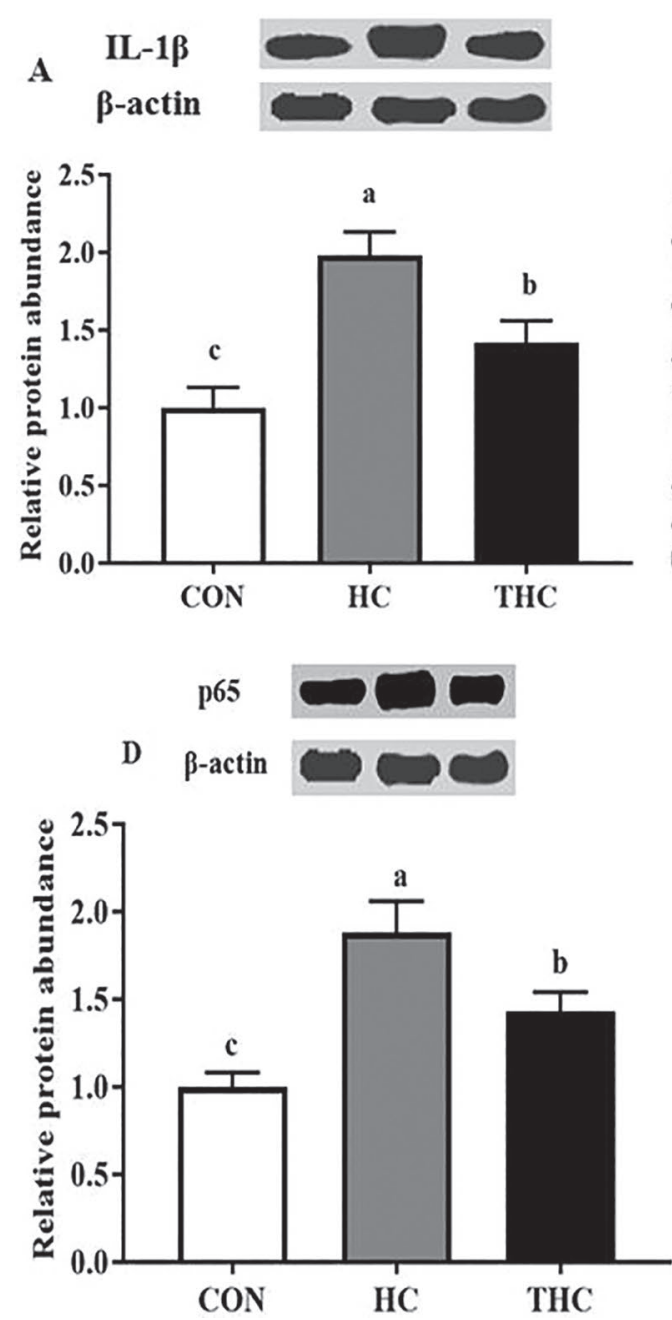
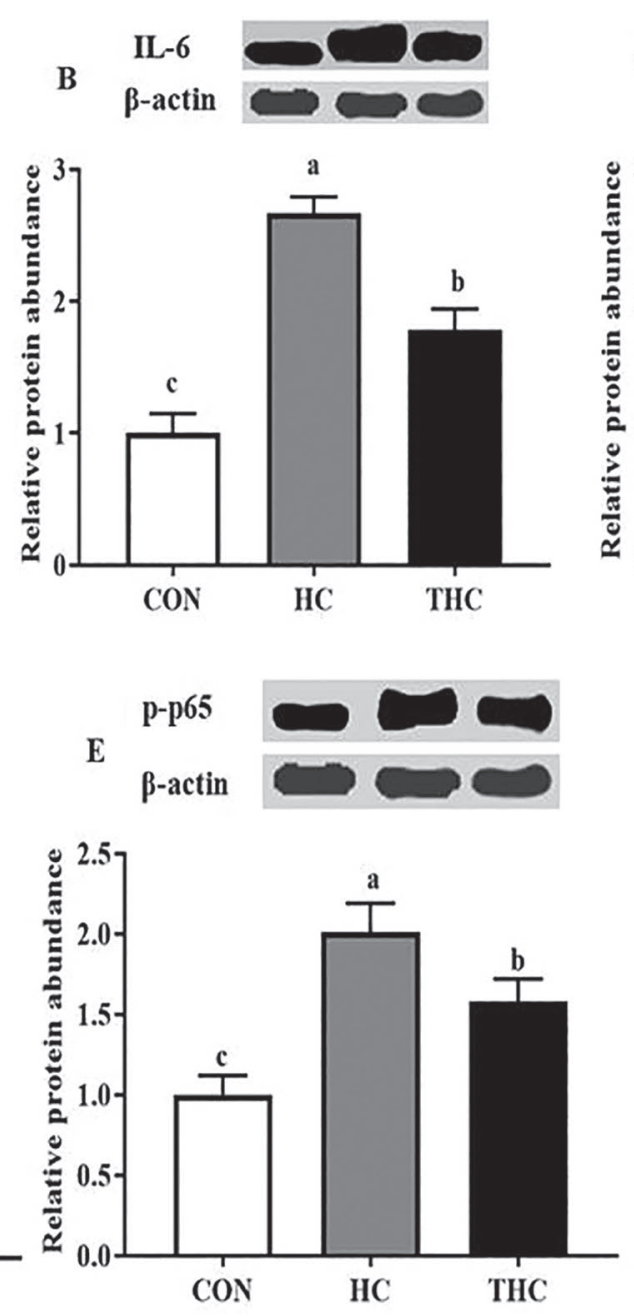

Figure 2. Effects of thiamine supplementation on the relative protein (A) IL-1ß, (B) IL-6, (C) tumor necrosis factor $\alpha$ (TNF- $\alpha$ ), (D) p65, and (E) p-p65 expression levels in the ruminal epithelium of dairy goats with SARA. The protein expression value equals densitometry units of selected protein/densitometry units of $\beta$-actin detected by Western blotting. Values are presented as means \pm SEM; $\mathrm{n}=6$ goats/group. Means within each protein with different letters $(\mathrm{a}-\mathrm{c})$ are significantly different $(P<0.05)$. CON $=$ control; HC $=$ high-concentrate diet; THC $=$ highconcentrate diet supplemented with $200 \mathrm{mg}$ of thiamine $/ \mathrm{kg}$ of DMI.

helped increase pyruvate flow into the TCA cycle and consequently decreased the flow of pyruvate to lactate. The latter is accomplished by first converting pyruvate into acetyl-CoA (PDH activity) and then enhancing the rate-limiting step in the TCA cycle, which is the conversion of $\alpha$-ketoglutarate to succinyl-CoA by $\alpha-K G D H C$. This effect eventually results in the reduction of pyruvate and lactate (Falder et al., 2010).

\section{Thiamine Attenuated Inflammatory Response}

Blood immune typing is a key approach that can be used to diagnose immunological disorders (Cao et al., 2016). In the current study, peripheral blood IgA concentration in $\mathrm{HC}$ goats was reduced compared with that in CON goats. This was in contrast with the greater plasma IL-1 $\beta$ in HC goats, which further indicated that the SARA induction successfully developed an inflammatory response.

The importance of TLR4 during the inflammatory response via the TLR4-MyD88-NF- $\mathrm{BB}$ axis signaling pathway has been clearly established (Kawai and Akira, 2009). Regulation of TNF- $\alpha$ and IL-6 release by IgA may be among the anti-inflammatory mechanisms preventing an uncontrolled release of potentially noxious levels of inflammatory cytokines during acute or chronic responses (Wolf et al., 1994). In this study, both mRNA and protein expression levels of ruminal proinflammatory cytokines such as IL-6 were remarkably upregulated in $\mathrm{HC}$ goats with SARA, which was consistent with a notable decline of plasma $\operatorname{IgA}$ in the same group. Similar to ruminal IL-6, plasma IL-1 $\beta$ 
as well as $I L 1 B$ mRNA expression in ruminal epithelium were upregulated in HC goats with SARA. Concomitantly to cytokines, SARA induction in the HC goats upregulated the mRNA expression of TLR4 and NFKB1 genes in the rumen, which is in agreement with a stimulated inflammatory response in this group. Interestingly, supplementation of thiamine in THC goats can be attributed to an attenuation of the inflammatory response induced by the high-concentrate diet; this was evident by a reduction in plasma IL- $1 \beta$ and gene expression of TLR4 and NFKB in the rumen. Taken together, the above findings suggested that thiamine could prevent inflammatory response in SARA goats.

Moreover, $\mathrm{CD} 8^{+} \mathrm{T}$ cells were increased in this study, which indicated impaired $\mathrm{T}$ cell development in $\mathrm{HC}$ goats under SARA conditions. Our results indicate that thiamine supplementation under SARA conditions (i.e., high-concentrate diets) improved blood monocyte, neutrophil, and lymphocyte concentrations and increased $\mathrm{CD}^{+}: \mathrm{CD}^{+}$ratio while reducing $\mathrm{CD} 8^{+}$ percentage, which suggests that thiamine can restore the compromised immune system in $\mathrm{HC}$ goats.

\section{Possible Mechanisms for Anti-Inflammatory Effects of Thiamine}

The effects of thiamine supplementation on local inflammation in the ruminal epithelium of THC goats could be associated with a reduced ruminal LPS content. Dai et al. (2017) reported that the endotoxin effects of LPS on ruminal epithelium were responsible for local inflammation under high-grain-induced SARA. At a molecular level, the increased LPS from gram-negative bacteria could be recognized by TLR4 in ruminal epithelium, which could then activate NF- $\mathrm{BB}$ and promote its nuclear translocation to induce the transcription of proinflammatory genes (Lin et al., 2008).

Suppressing NF- $\kappa$ B activation has been considered a critical target and practical approach to suppressing an inflammatory response (Lee et al., 2011). Consistent with previous research by Dai et al. (2017), our study indicated that feeding high-concentrate diets augmented the phosphorylation of NF- $\mathrm{B}$ p65 while upregulating the expression of proinflammatory cytokines in $\mathrm{HC}$ goats. Nevertheless, the upregulated expression of NF-кB p65 was reversed by thiamine supplementation in THC goats. Such findings implied that thiamine anti-inflammatory effects might be partially ascribed to suppression of NF- $\kappa \mathrm{B}$ activation. Furthermore, Bozic et al. (2015) also demonstrated that benfotiamine, a synthetic derived thiamine, was able to regulate the inflammatory response of macrophages to LPS, which was attained through inhibiting NF-кB p65 nuclear translocation. Taken together, our findings confirmed the anti-inflammatory properties of thiamine through inhibiting the NF- $\kappa \mathrm{B}$ activity mediated by TLR4, thereby downregulating the transcription of proinflammatory cytokines, such as $I L 1 B$.

\section{Thiamine Enhanced Ruminal Barrier Function}

Thiamine created a remarkable reduction in the activation and mRNA expression of MMP-2 and MMP-9 in ruminal epithelium when supplemented in highconcentrate diets. Tight junctions are special complex molecular structures in the stratum granulosum, which endowed the ruminal epithelium with mechanical strength; also, tight junction proteins along with the extracellular matrix are the main substrates for MMP (Kruger et al., 2015). Neutrophils represent a significant source of MMP, which results in tissue injury and remodeling (Kruger et al., 2015). Furthermore, NF- $\kappa$ B plays a role in triggering MMP activation (Wu and Schmid-Schonbein, 2011). As a result, thiamine supplementation to the diet can downregulate MMP-2 and MMP-9 expression and thereby enhance the barrier function of ruminal epithelium.

\section{CONCLUSIONS}

The results from this study suggest that local inflammation will be induced in goats fed the $\mathrm{HC}$ diet for $8 \mathrm{wk}$; that is reflected in a serious structurally and functionally compromised ruminal epithelium. Nonetheless, such adverse effects may be alleviated by thiamine supplementation, which is achieved through suppressing NF- $\kappa \mathrm{B}$ activation, inhibiting the synthesis of proinflammatory cytokines (i.e., IL-6 and TNF- $\alpha$ ), mitigating the infiltration of inflammatory cells, and reducing MMP activities. In this way, thiamine can maintain ruminal epithelial integrity as well as its barrier function in goats fed $\mathrm{HC}$ diets.

\section{ACKNOWLEDGMENTS}

The research was supported by the Project of National Key Research and Development Program of China (2017YFD0500500, Beijing), the National Natural Science Foundation of China (No. 31872988, Beijing), the Top Talents Award Plan of Yangzhou University (2016), National Natural Science Foundation of China (No. 31902180, Beijing), and the Research Project of Natural Science Foundation of Jiangsu Province (No. BK20170488, Nanjing, China). The authors express their thanks to Jie Sun in Hong Rong Wang's laboratory (Yangzhou University, Yangzhou, China), who contributed to the sample collection. The authors have not stated any conflicts of interest. 


\section{REFERENCES}

Aguirre, T. A., M. Rosa, S. S. Guterres, A. R. Pohlmann, I. Coulter, and D. J. Brayden. 2014. Investigation of coco-glucoside as a novel intestinal permeation enhancer in rat models. Eur. J. Pharm. Biopharm. 88:856-865. https://doi.org/10.1016/j.ejpb.2014.10.013.

Analytical Methods Committee. 2000. Determination of thiamine and riboflavin in pet foods and animal feedingstuffs. Analyst (Lond.) 125:353-360. https://doi.org/10.1039/a909461j.

Bozic, I., D. Savic, D. Laketa, I. Bjelobaba, I. Milenkovic, S. Pekovic, N. Nedeljkovic, and I. Lavrnja. 2015. Benfotiamine attenuates inflammatory response in LPS stimulated BV-2 microglia. PLoS One 10:e0118372. https://doi.org/10.1371/journal.pone.0118372.

Brent, B. E. 1976. Relationship of acidosis to other feedlot ailments. J. Anim. Sci. 43:930-935. https://doi.org/10.2527/jas1976.434930x.

Broderick, G. A., and J. H. Kang. 1980. Automated simultaneous determination of ammonia and total amino acids in ruminal fluid and in vitro media. J. Dairy Sci. 63:64-75. https://doi.org/10 .3168/jds.S0022-0302(80)82888-8.

Bubber, P., Z. J. Ke, and G. E. Gibson. 2004. Tricarboxylic acid cycle enzymes following thiamine deficiency. Neurochem. Int. 45:10211028. https://doi.org/10.1016/j.neuint.2004.05.007.

Cao, W., L. Xiao, G. Liu, T. Fang, X. Wu, G. Jia, H. Zhao, X. Chen, C. Wu, J. Cai, and J. Wang. 2016. Dietary arginine and N-carbamylglutamate supplementation enhances the antioxidant statuses of the liver and plasma against oxidative stress in rats. Food Funct. 7:2303-2311. https://doi.org/10.1039/C5FO01194A.

Castrillo, C., M. Mota, H. Van Laar, J. Martín-Tereso, A. Gimeno, M. Fondevila, and J. A. Guada. 2013. Effect of compound feed pelleting and die diameter on rumen fermentation in beef cattle fed high concentrate diets. Anim. Feed Sci. Technol. 180:34-43. https://doi .org/10.1016/j.anifeedsci.2013.01.004.

Chang, G., S. Zhuang, H. M. Seyfert, K. Zhang, T. Xu, D. Jin, J. Guo, and X. Shen. 2015. Hepatic TLR4 signaling is activated by LPS from digestive tract during SARA, and epigenetic mechanisms contribute to enforced TLR4 expression. Oncotarget 6:38578-38590. https://doi.org/10.18632/oncotarget.6161.

Chen, Y., D. Chen, G. Tian, J. He, X. Mao, Q. Mao, and B. Yu. 2012. Dietary arginine supplementation alleviates immune challenge induced by Salmonella enterica serovar Choleraesuis bacterin potentially through the Toll-like receptor 4-myeloid differentiation factor 88 signalling pathway in weaned piglets. Br. J. Nutr. 108:1069-1076. https://doi.org/10.1017/S0007114511006350.

Dai, H., X. Liu, J. Yan, Z. U. Aabdin, M. S. Bilal, and X. Shen. 2017. Sodium butyrate ameliorates high-concentrate diet-induced inflammation in the rumen epithelium of dairy goats. J. Agric. Food Chem. 65:596-604. https://doi.org/10.1021/acs.jafc.6b04447.

Edwin, E. E., and R. Jackman. 1970. Thiaminase I in the development of cerebrocortical necrosis in sheep and cattle. Nature 228:772774. https://doi.org/10.1038/228772a0.

Emmanuel, D. G., S. M. Dunn, and B. N. Ametaj. 2008. Feeding high proportions of barley grain stimulates an inflammatory response in dairy cows. J. Dairy Sci. 91:606-614. https://doi.org/10.3168/ jds.2007-0256.

Falder, S., R. Silla, M. Phillips, S. Rea, R. Gurfinkel, E. Baur, A. Bartley, F. M. Wood, and M. W. Fear. 2010. Thiamine supplementation increases serum thiamine and reduces pyruvate and lactate levels in burn patients. Burns 36:261-269. https://doi.org/10 .1016/j.burns.2009.04.012.

Fernando, S. C., H. T. Purvis 2nd, F. Z. Najar, L. O. Sukharnikov, C. R. Krehbiel, T. G. Nagaraja, B. A. Roe, and U. Desilva. 2010. Rumen microbial population dynamics during adaptation to a high-grain diet. Appl. Environ. Microbiol. 76:7482-7490. https:// doi.org/10.1128/AEM.00388-10.

González-Ortiz, M., E. Martinez-Abundis, J. A. Robles-Cervantes, V. Ramirez-Ramirez, and M. G. Ramos-Zavala. 2011. Effect of thiamine administration on metabolic profile, cytokines and inflammatory markers in drug-naive patients with type 2 diabetes. Eur. J. Nutr. 50:145-149. https://doi.org/10.1007/s00394-010-0123-x.

Gozho, G. N., D. O. Krause, and J. C. Plaizier. 2006. Rumen lipopolysaccharide and inflammation during grain adaptation and subacute ruminal acidosis in steers. J. Dairy Sci. 89:4404-4413. https://doi.org/10.3168/jds.S0022-0302(06)72487-0.

Gozho, G. N., D. O. Krause, and J. C. Plaizier. 2007. Ruminal lipopolysaccharide concentration and inflammatory response during grain-induced subacute ruminal acidosis in dairy cows. J. Dairy Sci. 90:856-866. https://doi.org/10.3168/jds.S0022-0302(07)71569 -2 .

Hazell, A. S., and R. F. Butterworth. 2009. Update of cell damage mechanisms in thiamine deficiency: Focus on oxidative stress, excitotoxicity and inflammation. Alcohol Alcohol. 44:141-147. https: //doi.org/10.1093/alcalc/agn120.

Holtershinken, M., A. Hohling, G. Wendelken, K. Elias, and H. Scholz. 2003. Einflusse auf den ruminalen Protozoenbesatz des Rindes (in vitro) Teil 2: Wirkung einer subklinischen Pansenazidose ohne und mit Thiaminsubstitution. Tierarztliche Praxis Grostiere 31:178182.

Hongwei, Z., W. Hongron, L. Xiang, C. Waiwai, and W. Zongyou. 2010. Effects of thiamin supplementation on rumen fermentation in goat on high-concentration substrate. China Dairy Cattle 3.

Jia, Y., R. H. Cong, R. S. Li, X. J. Yang, Q. W. Sun, N. Parvizi, and R. Q. Zhao. 2012. Maternal low-protein diet induces gender-dependent changes in epigenetic regulation of the glucose-6-phosphatase gene in newborn piglet liver. J. Nutr. 142:1659-1665. https://doi .org/10.3945/jn.112.160341.

Kadegowda, A. K., M. Bionaz, B. Thering, L. S. Piperova, R. A. Erdman, and J. J. Loor. 2009. Identification of internal control genes for quantitative polymerase chain reaction in mammary tissue of lactating cows receiving lipid supplements. J. Dairy Sci. 92:20072019. https://doi.org/10.3168/jds.2008-1655.

Karapinar, T., M. Dabak, and O. Kizil. 2010. Thiamine status of feedlot cattle fed a high-concentrate diet. Can. Vet. J. 51:1251-1253.

Karapinar, T., M. Dabak, O. Kizil, and E. Balikci. 2008. Severe thiamine deficiency in sheep with acute ruminal lactic acidosis. J. Vet. Intern. Med. 22:662-665. https://doi.org/10.1111/j.1939-1676 .2008.0094.x.

Kawai, T., and S. Akira. 2009. The roles of TLRs, RLRs and NLRs in pathogen recognition. Int. Immunol. 21:317-337. https://doi.org/ 10.1093/intimm/dxp017.

Khafipour, E., D. O. Krause, and J. C. Plaizier. 2009a. A grain-based subacute ruminal acidosis challenge causes translocation of lipopolysaccharide and triggers inflammation. J. Dairy Sci. 92:10601070. https://doi.org/10.3168/jds.2008-1389.

Khafipour, E., D. O. Krause, and J. C. Plaizier. 2009b. Alfalfa pelletinduced subacute ruminal acidosis in dairy cows increases bacterial endotoxin in the rumen without causing inflammation. J. Dairy Sci. 92:1712-1724. https://doi.org/10.3168/jds.2008-1656.

Kruger, P., M. Saffarzadeh, A. N. Weber, N. Rieber, M. Radsak, H. von Bernuth, C. Benarafa, D. Roos, J. Skokowa, and D. Hartl. 2015. Neutrophils: Between host defence, immune modulation, and tissue injury. PLoS Pathog. 11:e1004651. https://doi.org/10.1371/ journal.ppat.1004651.

Kumar, K. N., V. R. Shah, B. K. Parikh, and S. Sonde. 2015. Reversal of severe lactic acidosis with thiamine in a renal allograft recipient. Indian J. Crit. Care Med. 19:425-428. https://doi.org/10.4103/ 0972-5229.160293.

Lau, E., C. Marques, D. Pestana, M. Santoalha, D. Carvalho, P. Freitas, and C. Calhau. 2016. The role of I-FABP as a biomarker of intestinal barrier dysfunction driven by gut microbiota changes in obesity. Nutr. Metab. (Lond.) 13:31-37. https://doi.org/10.1186/ s12986-016-0089-7.

Lee, J. Y., H. Y. Choi, W. H. Na, B. G. Ju, and T. Y. Yune. 2014. Ghrelin inhibits BSCB disruption/hemorrhage by attenuating MMP-9 and SUR1/TrpM4 expression and activation after spinal cord injury. Biochim. Biophys. Acta Mol. Basis Dis. 1842:24032412.

Lee, K. C., H. H. Chang, Y. H. Chung, and T. Y. Lee. 2011. Andrographolide acts as an anti-inflammatory agent in LPS-stimulated RAW264.7 macrophages by inhibiting STAT3-mediated suppression of the NF-kappaB pathway. J. Ethnopharmacol. 135:678-684. https://doi.org/10.1016/j.jep.2011.03.068. 
Li, S., E. Khafipour, D. O. Krause, A. Kroeker, J. C. RodriguezLecompte, G. N. Gozho, and J. C. Plaizier. 2012. Effects of subacute ruminal acidosis challenges on fermentation and endotoxins in the rumen and hindgut of dairy cows. J. Dairy Sci. 95:294-303. https://doi.org/10.3168/jds.2011-4447.

Lin, S. T., Y. Wang, Y. Xue, D. C. Feng, Y. Xu, and L. Y. Xu. 2008. Tetrandrine suppresses LPS-induced astrocyte activation via modulating IKKs-I $\kappa \mathrm{B} \alpha-\mathrm{NF}-\kappa \mathrm{B}$ signaling pathway. Mol. Cell. Biochem. 315:41-49. https://doi.org/10.1007/s11010-008-9787-4.

Liu, J. H., T. T. Xu, Y. J. Liu, W. Y. Zhu, and S. Y. Mao. 2013. A high-grain diet causes massive disruption of ruminal epithelial tight junctions in goats. Am. J. Physiol. Regul. Integr. Comp. Physiol. 305:R232-R241. https://doi.org/10.1152/ajpregu.00068 .2013.

Livak, K. J., and T. D. Schmittgen. 2001. Analysis of relative gene expression data using real-time quantitative PCR and the $2-\Delta \Delta \mathrm{CT}$ method. Methods 25:402-408. https://doi.org/10.1006/meth.2001 .1262 .

Mao, S. Y., W. J. Huo, and W. Y. Zhu. 2016. Microbiome-metabolome analysis reveals unhealthy alterations in the composition and metabolism of ruminal microbiota with increasing dietary grain in a goat model. Environ. Microbiol. 18:525-541. https://doi.org/10 $.1111 / 1462-2920.12724$

Miller, B. L., J. C. Meiske, and R. D. Goodrich. 1986. Effects of grain source and concentrate level on B-vitamin production and absorption in steers. J. Anim. Sci. 62:473-483. https://doi.org/10.2527/ jas1986.622473x.

Neville, B. W., C. S. Schauer, K. Karges, M. L. Gibson, M. M. Thompson, L. A. Kirschten, N. W. Dyer, P. T. Berg, and G. P. Lardy. 2010. Effect of thiamine concentration on animal health, feedlot performance, carcass characteristics, and ruminal hydrogen sulfide concentrations in lambs fed diets based on $60 \%$ distillers dried grains plus solubles. J. Anim. Sci. 88:2444-2455. https://doi.org/ 10.2527/jas.2009-2607.

Nocek, J. E. 1997. Bovine acidosis: Implications on laminitis. J. Dairy Sci. 80:1005-1028. https://doi.org/10.3168/jds.S0022 $-0302(97) 76026-0$.

Pan, X., F. Xue, X. Nan, Z. Tang, K. Wang, Y. Beckers, L. Jiang, and B. Xiong. 2017a. Illumina sequencing approach to characterize thiamine metabolism related bacteria and the impacts of thiamine supplementation on ruminal microbiota in dairy cows fed highgrain diets. Front. Microbiol. 8:1818. https://doi.org/10.3389/ fmicb.2017.01818.

Pan, X. H., L. Yang, Y. Beckers, F. G. Xue, Z. W. Tang, L. S. Jiang, and B. H. Xiong. 2017b. Thiamine supplementation facilitates thiamine transporter expression in the rumen epithelium and attenuates high-grain-induced inflammation in low-yielding dairy cows. J. Dairy Sci. 100:5329-5342. https://doi.org/10.3168/jds .2016-11966.

Pan, X. H., L. Yang, F. G. Xue, H. R. Xin, L. S. Jiang, B. H. Xiong, and Y. Beckers. 2016. Relationship between thiamine and subacute rumen acidosis induced by a high grain diet in dairy cows. J. Dairy Sci. 99:8790-8801. https://doi.org/10.3168/jds.2016-10865.

Plaizier, J., E. Khafipour, S. Li, G. Gozho, and D. Krause. 2012. Subacute ruminal acidosis (SARA), endotoxins and health consequences. Anim. Feed Sci. Technol. 172:9-21. https://doi.org/10 .1016/j.anifeedsci.2011.12.004.

Plaizier, J. C., D. O. Krause, G. N. Gozho, and B. W. McBride. 2008 Subacute ruminal acidosis in dairy cows: The physiological causes, incidence and consequences. Vet. J. 176:21-31. https://doi.org/10 $.1016 / j . t v j 1.2007 .12 .016$.
Qin, W. L. 1982. Determination of rumen volatile fatty acids by means of gas chromatography. J. Nanjing Agric. Coll. 4:110-116.

Russel, A. J. F., J. M. Doney, and R. G. Gunn. 1969. Subjective assessment of body fat in live sheep. J. Agric. Sci. 72:451-454. https: //doi.org/10.1017/S0021859600024874.

Saremi, B., H. Sauerwein, S. Danicke, and M. Mielenz. 2012. Technical note: Identification of reference genes for gene expression studies in different bovine tissues focusing on different fat depots. J. Dairy Sci. 95:3131-3138. https://doi.org/10.3168/jds.2011-4803.

Shoeb, M., and K. V. Ramana. 2012. Anti-inflammatory effects of benfotiamine are mediated through the regulation of the arachidonic acid pathway in macrophages. Free Radic. Biol. Med. 52:182-190. https://doi.org/10.1016/j.freeradbiomed.2011.10.444.

Steele, M. A., O. AlZahal, S. E. Hook, J. Croom, and B. W. McBride. 2009. Ruminal acidosis and the rapid onset of ruminal parakeratosis in a mature dairy cow: A case report. Acta Vet. Scand. 51:39. https://doi.org/10.1186/1751-0147-51-39.

Wang, H., X. Pan, C. Wang, M. Wang, and L. Yu. 2015. Effects of different dietary concentrate to forage ratio and thiamine supplementation on the rumen fermentation and ruminal bacterial community in dairy cows. Anim. Prod. (Purwokerto) 55:189-193. https://doi.org/10.1071/AN14523.

Wolf, H. M., M. B. Fischer, H. Puhringer, A. Samstag, E. Vogel, and M. M. Eibl. 1994. Human serum IgA downregulates the release of inflammatory cytokines (tumor necrosis factor-alpha, interleukin-6) in human monocytes. Blood 83:1278-1288. https://doi.org/ 10.1182/blood.V83.5.1278.1278.

Wu, K. I., and G. W. Schmid-Schonbein. 2011. Nuclear factor kappa $\mathrm{B}$ and matrix metalloproteinase induced receptor cleavage in the spontaneously hypertensive rat. Hypertension 57:261-268. https:/ /doi.org/10.1161/HYPERTENSIONAHA.110.158709.

Yamane, K., I. L. Indalao, J. Chida, Y. Yamamoto, M. Hanawa, and H. Kido. 2014. Diisopropylamine dichloroacetate, a novel pyruvate dehydrogenase kinase 4 inhibitor, as a potential therapeutic agent for metabolic disorders and multiorgan failure in severe influenza. PLoS One 9:e98032. https://doi.org/10.1371/journal.pone .0098032 .

Zhang, H., F. Zhao, A. Peng, L. Dong, M. Wang, L. Yu, J. J. Loor, and H. Wang. 2018a. Effects of dietary L-arginine and N-carbamylglutamate supplementation on intestinal integrity, immune function, and oxidative status in intrauterine-growth-retarded suckling lambs. J. Agric. Food Chem. 66:4145-4154. https://doi.org/10 $.1021 /$ acs.jafc.8b00726.

Zhang, J., M. Wang, Z. Hao, L. Yu, and H. Wang. 2014. Effects of thiamine on concentrations of volatile fatty acids and lactate in culture medium of high concentrate substrate after in vitro rumen fermentation. Chinese J. Anim. Nutr. 26:489-495.

Zhang, K., M. Meng, L. Gao, Y. Tu, and Y. Bai. 2018b. Sodium butyrate improves high-concentrate-diet-induced impairment of ruminal epithelium barrier function in goats. J. Agric. Food Chem. 66:8729-8736. https://doi.org/10.1021/acs.jafc.8b03108.

\section{ORCIDS}

H. Zhang (๑ https://orcid.org/0000-0002-5046-9785

F. F. Zhao @ () https://orcid.org/0000-0003-0845-8908

J. S. Osorio ๑ https://orcid.org/0000-0001-6192-0917

H. R. Wang @i https://orcid.org/0000-0002-4980-1082 